\section{Menyoal Ketubuhan dan Nilai Performatifnya}

\section{F. X. Widaryanto ${ }^{1}$}

Program Studi Seni Tari, Institut Seni dan Budaya Indonesia Bandung

\begin{abstract}
Corporeality as an existance of human body related to object and subject around is interesting to be explored, not only its capasity as an instrument of ritual purposes but also as instrument of its daily "performative" expression. The kinetic art is not considered belong to dance genre. It can be seen that the genre is expanded to be fluid so that one finds a difficulty to define performance style which not convensionally has form patterns indicated by its kinetic genealogy. Through a profundity of the observation of human body motion related both culturally and naturally to spatial "ecosystem," one can see the performative value instead of its conventional performance characterized by the form of its creative tradition. Furthermore, contemporarily it can be indicated that corporeality with performative values has a lot of opportunities to contribute significantly within various aspects of ecocriticism. This is a kind of a critical thinking in term of an efford to remind everybody to be aware of the relationship between human and the environmental problems.
\end{abstract}

Keywords: corporeality; ecocriticism; performative value

\section{Pendahuluan}

Terganggunya intimitas hubungan yang bersifat etis antara manusia dan alam dapat ditengarai dengan baik karena terlihat dengan kasat mata di berbagai daerah di negeri ini. Di musim hujan, banjir dan longsor terjadi di mana-mana, sementara di musim kemarau, kekeringan sangat dirasakan oleh para petani dan penduduk kota yang kehilangan mata air alami di lingkungan mereka. Hal ini adalah salah satu penanda belum sempurnanya proses ekosistem dalam "diri" atau "tubuh" lingkungan alam yang kemudian memunculkan pengaruh negatif pada diri tubuh-tubuh manusia. Apalagi bila kemudian kita lihat adanya fenomena ter[di]bakarnya hutan sebagai konservasi sumber daya air maka terlihatlah adanya sebuah proses kapasitas sumber daya air yang hilang dan berubahnya fungsi hutan menjadi hutan produksi. Secara mendasar terlihat bahwa perubahan inilah yang kemudian menginterupsi dan mengubah irama kehidupan alam yang berakibat pada sulitnya pengetahuan dan teknologi menetapkan prediksi yang berkaitan dengan tatahubungan antarmanusia dan lingkungannya bagi kesejahteraan umat manusia (Widaryanto, 2015: xiii).

Manusia dengan ketubuhannya di masa lalu memiliki sensibilitas yang tinggi kaitannya dengan perubahan "perilaku" alam yang memberinya hidup secara langsung dari hasil bumi, dalam hubungannya dengan intuisi purbawi, yaitu atas hasil pengolahan tanah yang merujuk pada harmoni ketubuhan itu sendiri. Artinya, relasi antartubuh dan lingkungan terus-menerus dibangun dalam spiritualitas yang khas, dengan merujuk pada etika relasi intersubjektif yang dimanifestasikan dalam berbagai proses dan bentuk ritual yang khas, atas dasar keseimbangan ekosistem yang diakrabi oleh suatu komunitas masyarakat tertentu. Pada masa kini, setelah muncul berbagai pendidikan ketubuhan (secara mainstream sebut saja tari, teater, musik), nilai-nilai spiritual itu direduksi dalam laku keterampilan tubuh yang terbatas dan hanya sampai pada tataran teknik semata-mata. Maka, relasi yang terjadi pun tidak sampai pada tataran wacana yang tidak terbatas. Paradoks tubuh

$1 \quad$ Alamat korespondensi: Institut Seni dan Budaya Indonesia Bandung. Jl. Buah Batu No. 212 Bandung. E-mail: fxwidar41@gmail.com; HP: 085314126795 
yang terbatas dan wacana yang tidak terbatas inilah yang menjadi hakikat pergulatan proses dan produk kreatif karya Sardono W. Kusumo. Aspek sensibilitas ketubuhannya sudah terlampaui dan aspek wacana atau konseptualisasinya terus berkembang dalam kekuatan ekokritikisme yang tidak ada henti-hentinya "diteriakkan" dalam berbagai kolaborasi ketubuhan.

Teks-teks dari proses dan produk kreatifnya yang berupa pertunjukan yang didominasi oleh garap ketubuhannya, telah meneriakkan fenomena perilaku "menyimpang" manusia masa kini yang mulai memperlihatkan kuasa dirinya dalam mengeksploitasi berbagai sumber daya alam dan tentunya kemudian kehilangan kesadarannya pada etika lingkungan hampir di seluruh penjuru tanah air. Di sisi lain, ia juga terlibat dalam pengembangan "tradisi pemikiran" keraton kapujanggan dalam manifestasi penciptaan model-model kreativitas pada jenjang pendidikan pascasarjana di berbagai institusi pendidikan seni di Indonesia. Sentuhan dimensi kritis pada eksplorasi ketubuhan dengan segala permasalahan wacana yang menyertainya, terus-menerus dilontarkannya dalam berbagai kesempatan negosiasi tubuh dengan lingkungannya. Di sinilah Guru Besar Penciptaan Seni yang disandangnya membawanya pada sharing tiada henti tentang pengalaman penciptaan seni yang terus menginterupsi dan meneriakkan nilainilai etika lingkungan dalam wacana ekokritikisme.

\section{Tubuh dan Lingkungan}

Dalam mengkaji permasalahan ketubuhan dan lingkungan, Bambang Sugiharto (Widaryanto, 2015: ix) memberikan alternatif menarik dengan perspektif yang mengaitkan hubungan tubuh primordial dan bumi, dalam pengalaman chthonic sebagai berikut:

Bila kita bicara perkara alam yang kita huni dan hayati sehari-hari, sebenarnya diperlukan sudut pandang lain juga, yakni dari sisi pengalaman chthonic primordial ("khthõnic"Yunani: berkaitan dengan bumi). Ini adalah pengalaman pergaulan tubuh dengan konteks alamiah lokal yang lantas terekam dalam ingatan korporeal, dalam insting tubuh dan pengetahuan badani (embodied knowledge). Pengalaman macam ini tentu kompleks dan biasanya tak terartikulasikan. Ia muncul dalam bahasa tubuh dan sikap batin dasar atas lingkungan, namun lebih eksplisit dan menyentuh dalam bentuk ungkapan-ungkapan seni lokal: dalam pola gerak tari, keunikan teknik vokal, tata-laku ritual, atau bahasa visual yang khas. Dengan kata lain, dari sudut pengalaman ketubuhan itu, kesadaran atas persoalan lingkungan memang umumnya menggumpal secara tajam dalam seni tradisional dan sensibilitas para senimannya.

Interaksi tubuh dan habitat ruang awalnya merupakan berbagai kebiasaan yang direkomendasikan secara turun-temurun dalam sebuah komunitas. Dari berbagai kebiasaan itulah, sekecil apa pun, yang kemudian membudaya di kalangan mereka dan bisa dirasakan sebagai sebuah sekuritas hidup. Misalnya, cara berjalan orang-orang Dayak. Ketika berjalan di tengah hutan, orang-orang Dayak menghentakkan kaki-kaki mereka sehingga ular-ular pun menyingkir dan tidak saling melukai di antara mereka.

Demikian juga interaksi tubuh dengan cardinal point (empat arah mata angin) dalam tarian Bugaku di Jepang, yang dilakukan selengkapnya mengarah ke empat arah mata angin untuk menghormati munculnya bulan purnama di malam hari. Hal tersebut terjadi juga pada tari Srimpi yang terdiri dari empat penari yang merepresentasikan posisi sultan yang melindungi dirinya dengan fenomena cardinal point dengan pancer atau pusatnya di Keraton Yogyakarta. Di sebelah utara ada Merapi, sebelah selatan ada Ratu Laut Selatan, Pesanggrahan Ambarketawang di sebelah barat, dan di sebelah timur ada astana atau makam Sultan Agung di Imogiri. Masingmasing penari sebagai pusat cardinal point juga beberapa kali melengkapi arah hadap tubuhnya untuk memperoleh keseimbangan relasi antara sultan sebagai dewaraja dan lingkungan yang pada hakikatnya adalah hubungan antarmanusia dan bumi. 
Keseimbangan relasi tubuh dan lingkungannya atau ruang eksistensinya, dalam budaya Jawa, bahkan realitanya sudah dipersiapkan sebelum tubuh mengawali siklus kehidupannya. Hal tersebutterlihatdariadanya bayi dalam kandungan yang sudah didoakan agar mendapatkan perlindungan dari empat arah mata angin tersebut. Doa dalam tembang ini ditulis dalam Sêrat Tåtåcårå (1911) oleh Padmosusastra (Widaryanto, 2015: 85-87) yang berbentuk måcåpat sêkar Pangkur.

Untaian atau cakêpan Pangkur ini memberikan spatial statement (pernyataan ruang) agar didapat sebuah cardinal point yang aman dan terbebas dari segala gangguan, baik lahir maupun batin. Harapannya, bila sang bayi lahir, ia telah memiliki ruang dan lingkungan baru yang aman bagi dirinya, baik secara fisikal maupun spiritual.

Demikian juga dengan berbagai fenomena tari di Jawa. Adalah menarik untuk melihat nama-nama gerak atau kualitas gerak tarinya sendiri yang ditandai dengan fenomena flora dan fauna, seperti pucang kanginan, gajah ngoling, nggrudha, prenjak tinaji, ganggeng kanyut, sekar suwun, cindhil ngungak tumpeng, kebo nggambul, mblarak sempal, ${ }^{2}$ dan lain-lain. Pernyataan nama-nama gerak tubuh dalam tari Jawa ini merupakan refleksi hubungan etis antartubuh dengan alam yang terungkap secara eksplisit di antara seniman, kekuasaan, dan harmoni alam yang terus berkelindan dalam berbagai ritual tubuh di keraton. Berbagai tabu terkait dengan "apropriasi" tubuh pun disematkan oleh otoritas kekuasaan, sehingga sifat dan sakralitas ritual yang dilakukan tetap terjaga kesuciannya. Hal ini dapat dilihat dari dilarangnya tubuh perempuan yang sedang mengalami menstruasi untuk mengeksekusi tari bedhaya Semang di Jawa, atau bahkan hanya tubuh yang belum mengalami menstruasi saja yang layak mengeksekusi tarian Legong di Bali.
Banyak sekali apropriasi ketubuhan yang dikaitkan dengan negosiasi isoterik dalam berbagai local genius di Indonesia. Tradisi kreatif para empu seni di berbagai wilayah di Indonesia masih meninggalkan jejakjejaknya dalam berbagai mitos, artifak, dan tradisi lisan yang sayangnya terus tergerus oleh perubahan biosphere dan cybersphere yang membuat tercerabutnya nilai-nilai etika tubuh yang membenturkan energi tubuh dengan energi bumi, dalam berbagai manifestasinya. Hal inilah yang menjadikan intimitas hubungan antarkeduanya menjadi semakin menjauh, sehingga "sensibilitas" yang dimiliki keduanya menjadi semakin tipis. Tak urung hubungan intersubjektivitas yang pernah dimilikinya di masa lalu secara pasti telah berubah menjadi hubungan subjek dan objek yang saling mengeksploitasi dan "saling menghancurkan". Permasalahan inilah yang mestinya perlu disadari bersama, dan salah satunya adalah melalui appeal dan teriakan tubuh dalam berbagai manifestasi baru pertunjukan ketubuhan.

\section{Migrasi Tubuh dan Interaksi Sosial}

Tubuh tidak bisa dilepaskan dengan mobilitas dan interaksinya dalam ruang dan waktu. Dewasa ini mobilitas tubuh dalam construct individunya sangat beragam. Mulai dari yang hanya bergeser dari kamar ke kamar sebuah rumah, dari rumah ke kantor tempat kerjanya, atau dari kota yang satu ke kota yang lainnya, sampai dengan mobilitas lintas negara yang membuat seseorang mengalami jetlack karena tiba-tiba tubuh harus menyesuaikan kembali dengan waktu yang tak seiring dengan ritme kehidupan reguler yang dialaminya.

Otoritas pergerakan tubuh kekinian tidak lagi ditopang oleh tubuh itu sendiri, tetapi sudah dibantu oleh sarana transportasi, baik itu dengan tenaga manual maupun yang

\footnotetext{
Pucang kanginan adalah pinang (areca catechu) tertiup angin; gajah ngoling berarti gajah yang sedang marah; nggrudha memiliki makna menjadi seperti garuda; prenjak tinaji adalah sejenis burung (prinia familiaris) yang lincah; ganggeng kanyut adalah sejenis lumut yang hanyut; sekar suwun adalah bunga yang diangkat di atas kepala; cindhil ngungak tumpeng menunjukkan anak tikus yang melongok nasi tumpeng; kebo nggambul adalah kerbau yang menggerakkan tanduknya ke atas; dan mblarak sempal menunjukkan seperti gerak daun kelapa kering yang lepas dari pohonnya (Widaryanto, 2015: 241-244).
} 
ditunjang dengan tenaga mesin. Alur geraknya diatur dalam sebuah regulasi lalu-lintas, yang mestinya memperlancar mobilitas tubuhtubuh itu sendiri dalam sebuah interaksi ikonik ataupun interaksi intersubjektif yang sangat mekanik. Prinsip efisiensi waktu dan efektivitas ruang serta jarak yang ditempuhnya menjadi prioritas tersendiri. Proses mobilitas itu sendiri, dalam spektakulasi jumlah, kini telah mewujud menjadi sesuatu yang memiliki nilai performatiftersendiri. Disana-sinimuncul interaksi dramatik bila ada tubuh-tubuh yang keluar dari sistem alur lalu lalang yang mengakibatkan terhambatnya berbagai proses mobilitas yang ada. Di ruang publik yang lain, sebuah stadion sepakbola misalnya, tubuhtubuh yang sekaligus juga berperan sebagai penonton terlihat homogen karena adanya integrasi sosial yang punya kepentingan pada pihak yang dijagokannya. Tubuh-tubuh massal dari para pihak digerakkan oleh sosok kunci di depan dengan berbagai cara dan alat tambahan untuk menarik perhatian sekaligus mengatur gerak dan irama yang secara massal memiliki spektakulasi performatif tersendiri. Bukan tidak mungkin terjadi konflik massal karena kerumunan yang ada terluka oleh kerumunan yang lain. Dari sisi bentuk fenomena tubuh massal ini terdapat nilai performatif tersendiri yang terkadang tidak disadari oleh tubuhtubuh individual yang ada.

Tubuh dalam migrasi sehari-hari juga memerlukan adanya sebuah ritus 'traveloka' atau 'perjalanan wisata' antara lain mengalami dan bersentuhan dengan berbagai keunikan dalam berbagai situs, baik yang bernuansa alami, religi, ataupun yang berkaitan dengan benda-benda ikonik yang tidak dimiliki oleh seseorang dalam kultur kehidupannya. Di sini tubuh mengalami interaksi dengan berbagai fenomena alam, baik laut, gunung, sungai, lembah, maupun berbagai fenomena objek dan lokasi yang unik. Tubuh mengalami ketakjuban yang mengarah pada nilai-nilai spiritualitas beyond its visualized. Demikian juga dengan berbagai situs religi yang semestinya banyak membuka hati dan memperluas cakrawala toleransi yang sangat dibutuhkan dalam hidup kebhinekaan di Indonesia dewasa ini. Hal ini mengingat adanya keberbagaian localgenius yang menarik tubuh untuk bermigrasi dan mengalami interaksi dengan aneka keunikan fenomena di antara anak-anak bangsa.

Dari antusiasme migrasi tubuh dan berbagai gerak masif kerumunan tubuh ke berbagai ruang publik di berbagai daerah, ternyata fenomena ini nyaris belum diimbangi dengan ketersediaan infrastruktur yang seutuhnya mampu memberikan kenyamanan mobilitas yang merata di berbagai wilayah. Hal ini terutama terjadi pada saat Lebaran dan Natalan, di mana migrasi tubuh dalam kerumunan interaksi sosial sering tidak ditopang dengan swarming intellegence. ${ }^{3}$ Banyak sekali terjadi insiden tabrakan yang membawa banyak derita tubuh, bahkan sampai dengan mortalitas tubuh yang tidak sedikit jumlahnya.

Di sela-sela dari banyak kerumunan ini terselip seniman dari berbagai disiplin yang mulai menyadari eksistensi dirinya, eksistensi tubuhnya dalam berbagai interaksi dengan subjek ataupun objek dalam ruang dan waktu tertentu. Mereka mulai menyadari bahwa tubuh-tubuh dalam berbagai dimensi kehidupan sudah selayaknya memaknai eksistensinya dalam sebuah kedalaman spiritualitas hidup,

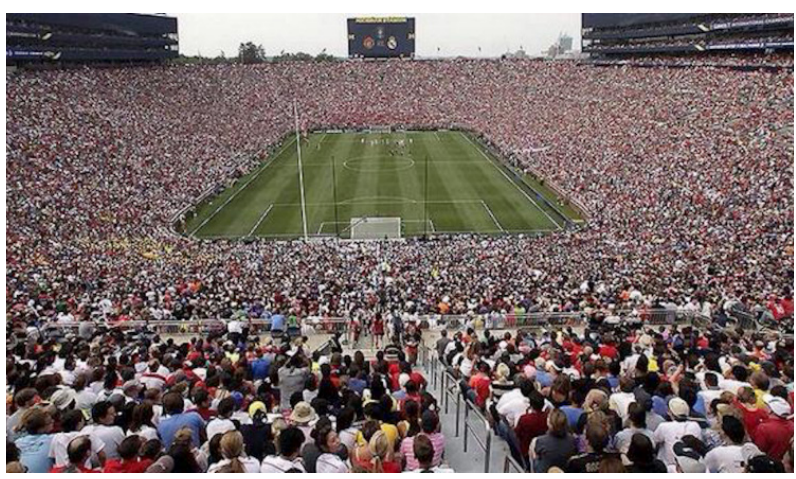

Gambar 1. Tubuh-tubuh penonton sepakbola di Stadium Football Ann Arbor yang konon diklaim berjumlah 109.318 orang pada tahun 2014 yang dicatat oleh asosiasi sepakbola Michigan United Football Club. (https://twitter.com/unitedarmyfc/ status/495723916803833856)

\footnotetext{
Swarming intellegence adalah kemampuan mengatur diri untuk tidak saling bertabrakan seperti kelompok kerumunan ribuan kelelawar yang kembali ke gua tempat mereka tinggal dan istirahat.
} 
sehingga interaksi yang dilakukannya tidaklah bersifat fisikal semata, tetapi juga lebih memiliki makna spiritual dan transendental. Dari sinilah diharapkan berbagai migrasi tubuh individual ataupun komunal, lebih memberikan interaksi etis antara energi bumi yang menghidupi dan energi tubuh yang merawatnya.

\section{Transparansi Tubuh Menurut Sardono W. Kusumo}

Sosok Sardono ini tidak hanya memiliki pengalaman primordialitas ketubuhan yang mampu berinteraksi dengan berbagai subjek dan objek dalam berbagai produk local genius di berbagai tempat di seluruh "penjuru angin", tetapi ia juga memiliki kemampuan unik dalam mengeksekusi kepekaan imajinasinya dalam media rupa.

Dengan cat berviskositas tertentu, dia memuncratkannya pada sebuah kanvas yang diletakkan miring sekitar $30^{\circ}$ dan kemudian menegakkan serta menggoyang-goyangnya sehingga cairan cat "menari-nari" dan meninggalkan jejaknya di atas kanvas. Oleh salah seorang curator, lukisannya disebut dengan Choreography of Color atau 'tarian warna', yang maknanya banyak mengungkap tentang tema lingkungan.

Obsesi tentang lingkungan hidup yang tergerus ekosistemnya menjadi salah satu gagasan dari 'tarian warna' yang menjadi ciri pencariannya dan telah dilakukannya selama puluhan tahun yang lalu. Danarto, penulis dan sastrawan, banyak menyaksikan gagasan kepekaan rupa dari tubuh yang tidak hanya menciptakan gerak, namun dari gerak itu tercipta ekspresi khas yang mewujudkan gerak menjadi kaya makna.

Gerak dalam eksplorasi ruangnya, menciptakan spatial multilayers atau 'lapislapis ruang' yang memungkinkan berbagai disiplin menggali kesadaran baru akan terciptanya rasa ruang yang tak pernah berhenti setelah mewujudkan bentuk, tetapi terus cair dan berubah dalam ruang baru yang terus cair seperti yang ada dalam bangun arsitektural Lawang Sewu di Semarang (Widaryanto dan Rustiyanti, 2013: 351) yang menginspirasinya menjadi konsep "kompilasi ruang" yang cair, dan tidak sempat membeku serta mewujud menjadi koreografi yang tertutup. Kata tertutup di sini menunjuk pada koreografi sebagai tatanan gerak yang sudah dirajut dalam sebuah entitas tari.

Entitas wujud ungkapan seni dalam lukisannya juga mengundang pengunjung untuk memberikan interpretasi kreatif dan kadang-kadang malah memunculkan chaos imaji baru seperti gagasan awal yang penuh dengan destruksi ruang. Ini bisa dilihat dari teknik proses kreatifnya yang juga dimunculkan pada pertunjukan Rain Coloring Forest pada 16-19 September 2010 di Los Angeles, Amerika Serikat (Widaryanto, 2015: 126). Kanvas yang dipenuhi dengan cipratan warna di atas pada saat yang dirasakan tepat ditegakkan secara vertikal dan dibiarkannya cat mengalir ke bawah. Kadang-kadang kanvas pun digoyang sehingga cat dengan warnawarni tertentu itu "menari-nari" mencari ruang sekaligus menciptakan ruang tersendiri yang memunculkan "hanya" elemen-elemen warna, bidang, serta ruang-ruang kosong yang memberi jeda warna kanvas yang dilukisnya. Lukisan inilah yang kemudian makin lama makin bertambah sehingga muncul tawaran untuk berpameran tunggal dari berbagai pihak. Di sinilah muncul gagasan baru tentang pameran lukisannya yang digagas kaitannya dengan corporeality beserta dimensi-dimensi ekspresivitas seni yang saling berinteraksi dalam ruang-ruang baru yang memiliki spesifikasi tersendiri sekaligus merupakan empowering dari dari berbagai genre yang saling berkelindan.

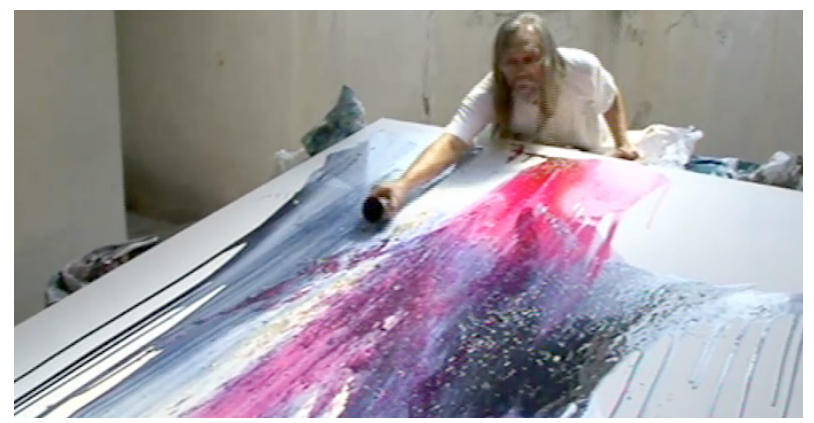

Gambar 2. Di tengah kejenuhan tubuh, imajinasi Mas Don terungkap dalam torehan lukisannya yang unik dan penuh dengan imaji gerak. (Foto: Koleksi Mas Don, 2014) 
Gagasan ini adalah sebuah wacana pembaruan untuk menyikapi proses kreatif tari. Sebagaimana diketahui bahwa tari sebagai salah satu cabang seni, yang pada awalnya hadir dari gagasan ritual, sosial, dan legitimasi dari berbagai komunitas etnis masyarakat, berkembang menjadi acuan penting dalam ranah seni pertunjukan. Tari telah memiliki batasan-batasan teknik, estetik, dan visual, yang pada era globalisasi ini ada tuntutan masyarakat penikmat, pemilik, pemerhati, dan pelakunya untuk tidak hanya disadarkan akan pentingnya harmoni dalam cakupan tari sebagai wacana pertunjukan saja. Namun cabang dan bidang seni di luar tari telah memilihnya untuk saling silang dalam interdisiplin dari berbagai bidang seni yang ada. Di sini para pelaku tari pada akhirnya juga telah banyak disadarkan, betapa bidang tari ternyata dapat lebih leluasa memasuki, menembus, dan melampaui batasbatas yang selama ini tidak pernah terusik keberadaannya. Tubuh mengalami proses "transparansi" dalam kohesinya dengan bidang seni yang lainnya. Bahkan Sardono baru-baru ini memberikan kecenderungan baru pada proses kreatif seni rupa/lukis selama Pameran Retrospeksinya di Singapore. Ia justru mengguyur hasil lukisannya di bawah air mancur untuk memberikan statement akan nilai 'kesementaraan' yang tidak harus menjadi tetapan produk justru pada seni yang hanya memiliki dimensi ruang. Bandingkan tubuh dengan nilai performatifnya yang memiliki dimensi ruang dan waktu dengan berbagai kompleksitas perubahan yang terjadi padanya (Widaryanto, 2016: 9 dan Emilia, 2016: 1-4). Ruang imajinatif yang cair dari empat arah mata angin bisa digambarkan dengan kotak tembus pandang yang terus berubah dan berpindah tempat seiring dengan penciptaan ruang dari tubuh-tubuh yang terus bergerak dalam satuan waktu tertentu. Orang sering menyebutkan "kotak" ini dengan white box.

Perkembangannya, "White box" merupakan sebuah gagasan ruang galeri seni rupa yang telah membuka diri untuk ikut "memeriahkan" ajang kolaborasi lintas bidang seni, yaitu dengan bidang musik, teater, sastra, dan tari.
Kolaborasi ini masih berada dalam batasanbatasan subjek penggagas yang berasal dari seni rupa. Yang terjadi kemudian adalah bahwa musik, teater/sastra, tari, serta bidang seni yang lain terlibat dalam kancah kegiatan seni rupa, namun hanya mampu mendampinginya secara kolaboratif untuk event Pembukaan dan/atau Penutupan pamerannya saja. Untuk itu, tawaran menari dalam "kotak putih" ini sebenarnya adalah sebuah tawaran yang sepatutnya dalam bidang tari untuk dapat memasuki ruang-ruang tanpa batas yang telah menyemarakkan wacana seni rupa dan seni tari di luar konvensi sebuah seni pertunjukan. Adanya argumentasi bahwa tari dengan leluasa mampu berdialog dengan gerak, koreografi, dan intelegensia kebertubuhannya, terlihat juga mampu menembus batas-batas rupa, visual, dan puitisasi dari sebuah kolaborasi lintas bidang di ranah seni rupa.

Tari dan galeri, bisa menjadi sebuah struktur yang secara sistemik mampu menyemaikan gagasan sebagai inkubator inovasi dalam proses kreatif berkesenian. Di sini terjadi pembentukan ataupun penciptaan gagasan/potensi/kapasitas serta keterampilan, teknik dan kepekaan interdisiplin bidang apa pun serta gagasan besar dalam cakupan silang budaya. Tari dan penari sebagai pelaku memerlukan dan dapat senantiasa menempatkan diri pada ruang-ruang publik, serta menjadikannya sebagai sebuah training kepekaan, intuisi, dan sensor dari berbagai gagasan kreatif. Oleh karenanya, galeri dalam konteks ini menjadi salah satu dimensi aktivitas di ruang publik, yang tak hanya memiliki dimensi ruang semata, tetapi juga dimensi waktu sebagaimana eksistensi plastis dari realita kebertubuhan yang tersaji.

Di sini kredo tari dalam manifestasi keterlibatannya sebagai peserta lintas disiplin membuka seluas-luasnya diri dan kebertubuhannya, serta memantapkan kemandirian, serta keingintahuannya justru untuk keluar dari batasan-batasan dalam tari dan seni pertunjukan itu sendiri. "Dancing on the White Box" adalah "out reaching the boundaries" yang merupakan sebuah sistem untuk keluar dari comfort zone yang selama 
ini menjadi batasan-batasan dalam konvensi seni pertunjukan.

Galeri seni rupa kontemporer saat ini sangat kuat ditandai oleh gagasan arsitektural, yang justru menawarkan karakter ruang yang berbeda dengan ruang dalam konvensi seni pertunjukan (joglo, teater arena, dan arsitektur pemanggungan barat/proscenium). Tawaran sistem white box ini menjadi penting karena tawarannya untuk berinteraksi dengan ruang seni rupa, yang konon lebih keras tarik menarik ruang publiknya karena adanya kebebasan interaksi sosialnya (terkait dengan memori kolektif). Dalam kaitan ini seni rupa tidak merawat kaitan sistem sosialnya sendiri, tetapi lebih mengacu langsung pada konsekuensi profesional individunya.

Dewasa ini, di sisi lain, eksplorasi ruang galeri juga sangat terbatas, di mana hanya dinding-dindingnya saja yang tereksploitasi. Ruang transparan di antara dinding-dinding pameran tak tersentuh oleh media tubuh sebagai subjek ekpresivitas seni. Di sinilah tubuh dengan kekuatan dirinya merengkuh sublimitas ruang dan merajutnya jauh melampaui dimensi ruang gerak dan menggapai sebuah fenomena "transparansi tubuh". Dengan kemampuannya bersinergi, yang terbuka dan membuka diri untuk memasuki ruang rupa yang kaya dengan dimensi visual dan arsitektural, proses jelajah tubuh ini berlangsung terus-menerus selama sebuah pameran berlangsung. Para penarinya memasuki interioritas ruang kebertubuhan, serta berkelindan dengan eksterioritas arsitektural tubuh yang mewujudkan ekspresivitas gerak, dalam ruang visual lukisan yang dipamerkannya.

Dengan demikian, dalam white box ini tubuh menjadi "transparan" karena saling menyerap bentuk, nilai, visual, auditif, tactile, pencerapan dan penciuman, serta struktur dari subjek di lingkungan itu yang tidak dibekukan di dalam kerangka koreografi namun luluh dalam interelasi koeksistensial dengan subjek-subjek di sekitarnya.

Untuk menindaklanjuti gagasan ini, Sardono W. Kusumo bekerjasama dengan Semarang Contemporary Art Gallery mengadakan pameran karya-karya lukis yang telah dikerjakannya sampai dengan tahun 2012. Kelekatannya dengan masalah lingkungan menjadikan peristiwa tsunami di Jepang pada tahun 2011 mendominasi hampir seluruh lukisannya, yang kemudian pamerannya diberi judul "Choreography of Color \#3" yang diselenggarakan pada bulan April 2012. Pamerannya bukan sekadar ekshibisi lukisan yang digantung pada dinding/panel vertikal di galeri, melainkan selama tiga minggu penuh setiap akhir pekan diadakan pertunjukan interaktif dari penari dan aktor pilihan dari berbagai kota di Indonesia, antara lain Bandung, Jakarta, Solo, Yogyakarta, Semarang, dan kota-kota lain di Jawa Timur.

\section{Melihat Proses dan Produk Kreatif Ketubuhan}

Di tebing sebuah bukit, yang ada di sekitar Candi Boko, ada beberapa orang yang merangkak. Di saat lain mereka berjalan berombongan, kadang berpisah dan kemudian menghilang di balik tebing yang lain. Tibatiba ada seseorang yang memanjat sebuah instalasi bambu yang berbentuk menyerupai sebuah "layar terkembang". Ditimpali iringan musik soundscape yang merupakan dengung dari suara-suara monofonik yang terasa menghipnotis, anak-anak muda itu terlihat melekat dan menyatu dengan anyaman bambu yang membawanya pada sebuah sensasi ruang, di halaman depan sebuah situs Candi Boko. Mereka tidak punya pretensi untuk menari. Tubuh-tubuh mereka membawa imaji yang hidup dan menghidupi kesadaran ruang yang baru bagi para penonton yang menatapnya.

Sosok-sosok muda itu kebanyakan penari, namun yang dilakukannya tidak lagi berbicara tentang estetika gerak tubuh dalam pemahaman konvensional, tetapi lebih terkait dengan fenomena gerak sehari-hari. Mereka digembleng dengan kesadaran tubuh saat sesi pelatihan kepekaan, salah satunya adalah dengan menatap bulan purnama. Mensyukuri ketakjuban fenomena alam dengan merasakan seluruh denyut, nafas, dan rangsang auditif ataupun rangsang visual. 
Menyadari keremangan cahaya bulan yang sesekali ditimpa oleh bayangan pesawat yang mau mendarat ke bandara di dekat pelataran Candi Baka, yaitu Bandara Adisucipto. Mereka "dipaksa" untuk menangkap bunyi yang didengarnya, mulai dari suara jangkerik dan dengung terdekat sampai dengan bunyi sayup-sayup yang terdengar dari berbagai arah. Kepekaan pendengaran mereka diupayakan seperti shotgun microphone yang mampu menangkap bunyi yang terletak di kejauhan. Demikian juga dengan kemampuan penglihatan mereka bak sebuah telescope untuk melihat lekuk-liku bulan yang terlihat "berjalan" karena pengaruh fenomena gerak gumpalan awan yang sering menutupi kehadirannya.

Anak-anak muda itu mencoba merasakan tubuhnya menjadi terbuka dan merespons berbagai rangsang di atas dalam gerak yang cair, tanpa pretensi menggerakkan tubuh dalam kinestetika yang terpola. Di sini muncul kinestika apa adanya yang memunculkan sebuah interaksi tubuh seseorang terkait dengan subjek atau objek di luar dirinya dalam gerak sehari-hari.

Gerak-gerak yang muncul kadang tampak sangat lambat seperti yang terlihat pada pertunjukan Butoh, sebuah aksi ketubuhan yang memunculkan misteri purbawi, dengan berbagai laku asketik yang sangat mendera kenyamanan tubuh itu sendiri. Betapa tidak. Orang bisa berjalan sangat pelan dari satu titik sepanjang lima meter untuk ditempuh dalam waktu setengah jam. Laku ini adalah cara "meditasi" yang lain dari para biksu yang disebut sebagai viphasana. Tubuh menahan kehendak untuk bergerak dan menyadari dirinya untuk menahan dan mengatur kecepatan "bergerak menuju...". Dalam prosesnya orang lebih menyadari konteks ruang dan kualitas kata kerja yang sedang dilakoninya. Maksudnya adalah kata 'mendengar' pada si pelaku berubah menjadi 'mendengarkan', dan kata 'melihat' cenderung menjadi 'mengamati'. Artinya, indera pendengaran dan penglihatan tidak hanya berfungsi apa adanya secara pasif, tetapi keduanya mengeksekusi bunyi dan objek secara lebih aktif. Dampak yang terjadi adalah munculnya rincian bunyi dan detail visual, yakni objek yang tadinya terasa sangat trivial 'sepele' dan tak berarti tiba-tiba berubah menjadi sangat signifikan.

Kesadaran di atas, yang tidak lain bermuara pada perkara sensibilitas ketubuhan, terus dipacu oleh Guru Besar Penciptaan Seni Sardono W. Kusumo. Ia memberikan contoh perkara ketubuhannya lewat model dirinya yang terus menerobos dan menyeruak dalam berbagai kultur komunitas masyarakat di Kalimantan, Nias, Bali, Papua, dan lainlain. Menurut Ignas Kleden, Sardono intens melakukan studi ketubuhannya dari dalam berbagai kultur yang dijelajahinya (2004: 1). Sardono mengatakan bahwa dirinya telah berupaya dengan tubuhnya menceburkan diri dalam "kolam budaya" dari berbagai komunitas tertentu di berbagai kantongkantong budaya (Sardono, 2013: Wawancara). Salah satu pengalaman menarik dalam penelitiannya di Papua adalah didapatnya kesadaran baru untuk mengeksplorasi dan mengembangkan teknik suara pada dirinya dan juga para penari atau mahasiswa yang secara intens berproses bersamanya dalam berbagai produksi kreatif yang ditanganinya. Saat eksplorasinya di berbagai desa Asmat, Sardono menemukan kebanyakan ekspresi gerak tubuh mereka tidak diiringi oleh instrumen-instrumen eksternal di luar tubuh sebagaimana layaknya yang terjadi pada umumnya. Apa yang dilihatnya adalah bahwa ekspresi mereka ternyata diiringi dengan instrumen suaranya sendiri yang baru menjadi "instrumen" ketika tubuh-tubuh mereka mulai menari. Ia mengawali ketertarikannya dengan fokus vokal mereka yang tak terkait dengan konvensi nada musik yang ada serta relasinya dengan gerak yang mereka lakukan.

Dari pemahaman di atas maka praktik vokal yang dilakukannya adalah ketika ia menjelajah dari desa yang satu ke desa yang lain dalam peta berbagai alur sungai yang kompleks, yang kerap kali mesti ditempuh selama tidak kurang dari enam jam perjalanan sungai. Suara lolongan yang diciptakannya sepanjang perjalanan ini mengingatkannya 
pada kualitas lolongan seekor serigala yang mengaum panjang dan lembut, yang suaranya dihasilkan dari dalam perut (Sardono, 2004: 126). Intensitas produk suara seperti ini bahkan terbawa dalam tidur temantemannya suku Asmat seperti yang kemudian diungkapkannya sebagai berikut:

"Bukan saja ketika menari, sering kali ketika lolongan ini lahir begitu saja ketika saya sedang tidur. Tak akan pernah kulupakan saat-saat tidur di pondok hutan bersama teman-teman suku Asmat. Di tengah malam aku terbangun dan mendapati suasana sunyi senyap. Semua orang tertidur, di luar gelap gulita. Mendadak, dalam keremangan cahaya, seorang terbangun sambil melolong keras dan panjang untuk kemudian kembali merebahkan badannya begitu suaranya habis di ujung pernapasannya. Kemudian terdengar kembali dengkur tidurnya, dan dalam beberapa saat hutan kembali senyap (2004: 126).

Lolongan ini secara intuitif merupakan statement keberadaan tubuh seseorang dalam habitat lingkungannya yang selalu waspada adanya binatang buas yang mendatanginya. Dengan kata lain, lolongan tersebut terkait dengan survival effort (upaya untuk hidup dan terlindungi) lebih daripada untuk mengiringi gerak semata dalam hidup dan menghidupi tubuh untuk merespons berbagai ritual adat yang dilakukannya.

Adakah hal ini masih terjadi? Dalam realita kehidupan masyarakat urban, tuntutan untuk kebutuhan survival ketubuhan menjadi berbeda. Realita biosphere yang dalam local genius bersifat natur sudah banyak mengalami transformasi dan berkelindan dengan realita cybersphere yang merasuk dalam interaksi ketubuhan yang virtual. Tubuh dalam kultur visual ini bisa menjadi sangat transparan dan "dihancurleburkan" untuk kemudian diwujudkan kembali dalam dimensi fisiknya. Ulang-alik penghayatan intensitas ruang fisik- ruang virtual ini semakin kuat mendominasi dalam jelajah envisioning ketubuhan ${ }^{4}$ dalam tatapan visual yang senyata-nyatanya. Inilah evolusi ketubuhan yang mulai marak dalam budaya visual yang melanda kehidupan kita dewasa ini.

Ada salah satu pernyataan menarik dari Josephine Machone dalam bukunya yang berjudul (Syn)aesthetics: Redifining Visceral Performance (2011: 1), seiring dengan fenomena chaotic ketubuhan yang diungkapkannya sebagai berikut:

"Since the late twentieth century a performance style has emerged which exploits diverse artistic languages to establish an 'experential' audience event via the recreation of visceral experience. Impossible to define as a genre due to fluidity of forms explored, this performance style places emphasis on the human body as a primary force of signification and utilizes the everincreasing possibilities in design and technology."

["Sejak akhir abad keduapuluh gaya sebuah pertunjukan telah muncul dengan sesuatu yang mengeksploitasi bahasa-bahasa artistik yang berbeda-beda untuk menetapkan sebuah 'eksperensial' dari peristiwa yang ditonton melalui penciptaan kembali suatu pengalaman yang mendalam. Ketidakmungkinannya dalam membuat batasan sebagai sebuah genre akibat fluiditas dari bentuk yang dijelajahinya, gaya pertunjukan ini menempatkan tekanannya pada ketubuhan sebagai kekuatan utama yang signifikan dan pemanfaatan berbagai kemungkinan dalam desain dan teknologi yang terus menerus berkembang"].

Di sini ada yang menarik dalam memberikan istilah kedalaman sebuah pertunjukan yang dikaitkan dengan visceral, yang berarti "jeroan" dan sangat mengait

$4 \quad$ Envisioning ketubuhan akhir-akhir ini banyak dilakukan oleh Garin Nugroho (Sutradara film) dengan berbagai karya yang mengeksploitasi tubuh dengan kekuatan optical approach sinematografi, seperti pada Opera Jawa dan Setan Jawa atau pada kumpulan filmnya My Family, My Film, and My Nation. 
secara fisik dengan ketubuhan dalam dimensi biosphere seutuh-utuhnya. Kedalaman tubuh dalam makna visceral memang tidak tampak secara kasat mata, namun fenomena ekspresi ketubuhannya telah menjanjikan tampilan penampakannya. Wacana ini bisa merupakan sebuah fenomena kedalaman yang bisa dibaca dengan pemahaman transparansi tubuh, seperti halnya gerbang kuil di Jepang, Torii, yang tanpa harus memasukinya orang telah melihat kuil yang ada di dalamnya (Mardohar B. B. Simanjuntak, 2017: 6).

Inilah yang melampaui ujaran yang terbatas pada sekelompok komunitas yang menguasai medianya namun belum tentu cukup sensibel dalam membaca teks yang disodorkannya. Sebaliknya dengan fenomena pengalaman primordialitas ketubuhan yang terlatih sepanjang hayat, ia akan selalu menangkap berbagai makna yang disodorkan dalam intuisi purbawi sekalipun. Kedekatan tubuh dengan subjek dan objek di sekelilingnya, menyadarkan kita pada nilainilai relasi intersubjectivity, kaitannya dengan subjek kehidupan biosphere, untuk terus disulut spirit sustainabilitasnya untuk saling menghidupi sepanjang waktu.

\section{Ketubuhan Indonesia?}

Dalam berbagai festival tari yang kemudian bergeser menjadi garap kolaboratif ketubuhan terlihat adanya ciri-ciri khas dari "nada dasar" tubuh-tubuh yang terlibat dalam proses dan produk yang kemudian ditampilkan, baik dalam forum festival atau pun post-festival. Istilah yang terakhir ini adalah upaya forum kreatif yang mewadahi berbagai lulusan atau alumni pendidikan tinggi yang terus "mengorganik" dalam berbagai karyanya di masyarakat. Eksistensi dari sosok-sosok tubuh kolaboratif ini bisa bersifat individual, komunal, ataupun institusional dalam berbagai dimensi kehidupan masyarakat kekinian. Dari sini akan terlihat betapa nilai-nilai ketubuhan akan tergali dalam sebuah gaung interaktif kultural, sekaligus fisikal dan spiritual.

Ada sebuah titik terang dalam olah ketubuhan, salah satunya yang ada di Bandung, yaitu diselenggarakannya sebuah DanceLab di sebuah galeri milik Nyoman Nuarta yang diwarnai dengan lingkungan hutan dengan 3000-an jenis pepohonan, yang disebut dengan Nuart Sculpture Park. Di sinilah beragam tubuh-tubuh Indonesia saling berinteraksi dengan pendampingan dari beberapa mentor yang mengalami proses ketubuhan di berbagai kultur dalam berbagai bentuk, baik kultur tanah maupun kultur air yang memang kemudian menjadi representasi keindonesiaan. ${ }^{5}$

Pada tataran yang makin tinggi, bentuk menjadi lebih cair dan makna estetis yang dikandungnya tak lagi eksklusif dan terkait dengan 'keindahan', yang oleh Katya Mandoki (2007: 7) disebut sebagai “[...] a linguistic effect used by a particular subject to describe personal experiences and social conventions, not things that exist independently of perception". [... sebuah pengaruh kebahasaan yang digunakan pada subjek tertentu untuk mendeskripsikan pengalaman personal dan konvensi sosial, bukan hal-hal yang ada dalam persepsi yang tak terikat"]. Di sinilah kemudian pengalaman pribadi dalam konteks jejak keragaman budaya sehari-hari dengan segala sensibilitasnya bisa berkelindan menjadi manifestasi baru tanpa harus diikat dalam bentuk yang kaku, namun memiliki kedalaman makna yang pada saatnya menelusup dan berpengaruh bagi terwujudnya kualitas hidup dalam berbagai bidang kehidupan.

\section{Penutup}

Tubuh yang tadinya dibentuk dengan pengenalan berbagai vokabuler gerak-gerak baku yang disepakati sebagai representasi ekspresi komunal mulai kehilangan jalinan linkage dengan tradisi komunalitasnya

\footnotetext{
Salah satu mentornya adalah Eko Supriyanto yang telah membawa karyanya Jailolo dan Bala-Bala, karya yang merepresentasikan tubuh-tubuh dalam budaya air dengan imaji levitasi yang nyaris membawa tubuh "tak bergravitasi".
} 
dan bermigrasi dalam sebuah gaya hidup modern yang didominasi dengan ekspresi individual dalam atmosfer akademik. Kecenderungan yang kemudian muncul adalah terkuaknya sebuah sensibilitas tubuh yang menjadikannya lebih pada kebebasan inividu dan terlepasnya ikatan-ikatan komunal yang kemudian menjadi lebih cair, sehingga bentuk menjadi sangat bersifat organik. Terjadilah "transparansi" ketubuhan yang membuka berbagai kemungkinan kolaboratif interkultur yang terus berproses mengindonesia. Inilah dialog yang terus diharapkan terjadi dengan menerabas lintas batas berbagai norma bentuk gerak milik berbagai kantung-kantung budaya masyarakat dengan local genius-nya, untuk menggali berbagai pesan toleransi. Dialogis dari berbagai perbedaan yang ada banyak dimunculkan pada berbagai festival tari, yang bahkan kemudian menjadi sebuah proses yang jauh lebih penting untuk menuju pada nilai-nilai keindonesiaan kontemporer.

\section{Kepustakaan}

Eko Supriyanto. 2017. "Tubuh Tari Indonesia: Sasi Kirana Dance Camp 2015-2016". Manuskrip [tidak diterbitkan].

Emilia, Stevie. 2016."Sardono's Unprecedented Retrospective". The Jakarta Post. Agustus, 23 2016. Page 1-4.

Kleden, Ignas. 2004. "Understanding Culture from Within: Notes from Essays by Sardono W. Kusumo. Paper. National Serial of Indonesian Performing Arts Seminar 19 \& 20 Juli 2004 ISI Surakarta. Machone, Josephine. 2011. (Syn)esthetics: Redifining Visceral Performance. New York: Palgrave Macmillan.

Mandoki, Katya. 2007. Everyday Aesthetics: Prosaics, the Play of Culture and Social
Identity. Hampshire: Ashgate Publishing Limited.

Mardohan B. B. Simanjuntak. 2017. "Jejalin Konstruksi Sinestetik Fotografi". Paper dalam Seminar Hari Estetika di Hotel Cokro Bandung.

Sardono W. Kusumo. 2004. Hanuman, Tarzan, Homo Erectus. Jakarta: Penerbit ku/bu/ ku.

Sugiharto, Bambang Ign., ed. 2013. Untuk Apa Seni? Bandung: Pustaka Matahari.

Widaryanto, F. X. 2015. Ekokritikisme Sardono W. Kusumo: Gagasan, Proses Kreatif, dan Teks-Teks Ciptaannya. Jakarta: Pascasarjana IKJ. . 2016. "Sardono W. Kusumo: Refleksi Sensibilitas Ketubuhan”. Paper pada Public Lecture Art Summit pada tanggal 8 September 2016 di Auditorium Pascasarjana Universitas Gadjah Mada.

Widaryanto F. X. dan Sri Rustiyanti. 2013. 'Konsep 'Lawang Sewu' atau 'White Box' sebagai Fenomena Baru Proses Kreatif Ketubuhan".Jurnal Ilmiah Seni \& Budaya Panggung Vol. 23 No. 4 Desember [Terakreditasi], hal. 342-356.

\section{Diskografi}

Painting Performance of Sardono W. Kusumo. Sardono W. Kusumo. Jakarta: Dokumentasi Pribadi, 2012.

\section{Informan}

Padmosusastro, 1911. Serat Tatacara. Semarang: Tuwan H. A. Benyamin dalam http://www.sastra.org/bahasa-dan-budaya/62-adat-dan-tradisi/264-tatacarapadmasusastra-1911-176-hlm-001-102. Diunduh 16 Desember 2013. 